\title{
ANALYSIS OF FIELD SEAGRASS PERCENT COVER AND ABOVEGROUND CARBON STOCK DATA FOR NON-DESTRUCTIVE ABOVEGROUND SEAGRASS CARBON STOCK MAPPING USING WORLDVIEW-2 IMAGE
}

\author{
P. Wicaksono ${ }^{1}$ *, P. Danoedoro ${ }^{1}$, Hartono ${ }^{1}$, U. Nehren ${ }^{2}$, A. Maishella ${ }^{3}$, M. Hafizt ${ }^{4}$, S. Arjasakusuma ${ }^{1}$, S. D. Harahap ${ }^{3}$ \\ ${ }^{1}$ Department of Geographic Information Science, Faculty of Geography, Universitas Gadjah Mada, Yogyakarta, Indonesia 55281 - \\ prama.wicaksono@ugm.ac.id, pdanoedoro@ugm.ac.id, hartono.geografi@ugm.ac.id, sanjiwana.arjasakusuma@ugm.ac.id \\ ${ }^{2}$ Institute for Technology and Resources Management in the Tropics and Subtropics (ITT) University of Applied Sciences, Cologne, \\ Germany 50679 - udo.nehren@ th-koeln.de \\ ${ }^{3}$ Cartography and Remote Sensing, Faculty of Geography, Universitas Gadjah Mada, Yogyakarta, Indonesia 55281 - \\ amanda.maishella@mail.ugm.ac.id, setiawandjody99@mail.ugm.ac.id \\ ${ }^{4}$ Research Center for Oceanography, Indonesian Research and Innovation Agency, Jalan Pasir Putih I, Ancol Timur 14430, Jakarta, \\ Indonesia-muhammadhafizt@gmail.com
}

KEY WORDS: Seagrass, Percent Cover, Above-Ground Carbon Stock, Mapping, WorldView-2

\begin{abstract}
:
Remote sensing can make seagrass aboveground carbon stock ( $\left.\mathrm{AGC}_{\text {seagrass }}\right)$ information spatially extensive and widely available. Therefore, it is necessary to develop a rapid approach to estimate $\mathrm{AGC}_{\text {seagrass }}$ in the field to train and assess its remote sensing-based

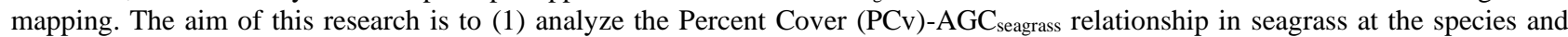
community levels to estimate $\mathrm{AGC}_{\text {seagrass }}$ from PCv and (2) perform $\mathrm{AGC}_{\text {seagrass }}$ mapping at both levels using WorldView-2 image and assess the accuracy of the resulting map. This research was conducted in Karimunjawa and Kemujan Islands, Indonesia. Support Vector Machine (SVM) classification was used to map seagrass species composition, and stepwise regression was used to model AGC $\mathrm{Aeagrass}$ using deglint, water column corrected, and principle component bands. The results were a rapid $\mathrm{AGC}_{\text {seagrass }}$ estimation using an easily measured parameter, the seagrass PCv. At the community level, the $\mathrm{AGC}_{\text {seagrass }}$ map had $58.79 \%$ accuracy $\left(\mathrm{SEE}=5.41 \mathrm{~g} \mathrm{C} \mathrm{m}^{-2}\right)$, whereas at the species level, the accuracy increased for the class $\mathrm{Ea}\left(64.73 \%, \mathrm{SEE}=6.86 \mathrm{~g} \mathrm{C} \mathrm{m}^{-2}\right)$ and $\mathrm{EaThCr}(70.02 \%, \mathrm{SEE}=4.32$ $\left.\mathrm{g} \mathrm{C} \mathrm{m}^{-2}\right)$ but decreased for $\mathrm{ThCr}\left(55.08 \%, \mathrm{SEE}=2.55 \mathrm{~g} \mathrm{C} \mathrm{m}^{-2}\right)$. The results indicate that WorldView-2 image reflectance can accurately map $\mathrm{AGC}_{\text {seagrass }}$ in the study area in the range of 15-20 $\mathrm{g} \mathrm{C} \mathrm{m}^{-2}$ for Ea, 10-15 $\mathrm{g} \mathrm{C} \mathrm{m}^{-2}$ for EaThCr, and 4-8 $\mathrm{g} \mathrm{C} \mathrm{m}^{-2}$ for ThCr. Based on our model, the $\mathrm{AGC}_{\text {seagrass }}$ in the study area was estimated at $13.39 \mathrm{t} \mathrm{C}$.
\end{abstract}

\section{INTRODUCTION}

The integration of remote sensing and field data for mapping aboveground carbon stock of seagrass $\left(\mathrm{AGC}_{\text {seagrass}}\right)$ requires corresponding field data to train the regression model and assess the accuracy of the resulting map (Hossain et al., 2015; Tamondong et al., 2018). However, the process of obtaining this data is destructive, costly, and time-consuming (Misbari, 2017); hence, it is necessary to develop a fast and non-destructive approach to estimate $\mathrm{AGC}_{\text {seagrass }}$ for use in training and validating remote sensing-based AGC mapping.

Equations to approximate AGC from easily measured parameters, such as percent cover, are currently available (Wahyudi et al., 2020) and are especially useful for $\mathrm{AGC}_{\text {seagrass }}$ appraisal without considering species uniqueness. However, this study proposed a new alternative for predicting $\mathrm{AGC}_{\text {seagrass }}$ using percent cover $(\mathrm{PCv})$ while also factoring in the unique $\mathrm{PCv}$ $\mathrm{AGC}_{\text {seagrass }}$ relationship of each species. In addition to developing a species-specific $\mathrm{PCv}-\mathrm{AGC}_{\text {seagrass }}$ equation, we also integrate WorldView-2 multispectral remote sensing images with in situ $\mathrm{AGC}_{\text {seagrass }}$ data, calculated using the $\mathrm{PCv}-\mathrm{AGC}_{\text {seagrass }}$ equation, to map $\mathrm{AGC}_{\text {seagrass. }}$

To achieve these objectives, this study measured seagrass PCv in the field and $\mathrm{AGC}_{\text {seagrass }}$ in the laboratory and analyzed their relationship. We acknowledge that the interaction between seagrass biophysical properties may only work effectively at the species level (Duffy, 2006). Species uniqueness controls variations in leaf size, life form, leaf distribution, leaf density, organic carbon distribution in above and belowground biomass, and the rate of inorganic carbon sequestration (Bell et al., 2006; Duffy, 2006). For example, 50\% PCv of Enhalus acoroides might consist of a few tens of shoots, while $40 \%$ PCv of Thalassia hemprichii might be populated by hundreds of shoots because of its smaller size. These variations may lead to a weak correlation between seagrass biophysical properties, especially $\mathrm{AGC}_{\text {seagrass, }}$ and seagrass reflectance.

Therefore, this research mapped the $\mathrm{AGC}_{\text {seagrass }}$ at species and community levels, and specifically aimed to (1) analyze the $\mathrm{PCv}$ $\mathrm{AGC}_{\text {seagrass }}$ relationship in seagrass at both levels, enabling the

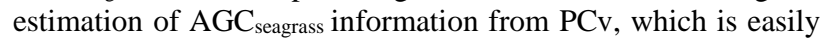
measured, and (2) conducting $\mathrm{AGC}_{\text {seagrass }}$ mapping at the community and at the species level using WorldView-2 image and assess the accuracy of the resulting map.

\section{STUDY AREA}

This research was carried out in four members of the Karimunjawa Islands in Indonesia, namely Karimunjawa Island, Kemujan Island, Menjangan Besar Island, and Menjangan Kecil Island (Figure 1). These areas were selected as they represent

\footnotetext{
$1 *$ Corresponding author
} 
seagrass beds with a variety of seagrass species and distribution patterns. Since 1999, they have been part of the Karimunjawa National Park under the authority of the Indonesian Ministry of Forestry. Several seagrass species found in the study area are Enhalus acoroides (Ea), Halophila ovalis (Ho), Thalassia hemprichii $(\mathrm{Th})$, Cymodocea rotundata $(\mathrm{Cr})$, Cymodocea serrulata $(\mathrm{Cs})$, Halodule pinifolia $(\mathrm{Hp})$, Halodule uninervis $(\mathrm{Hu})$, Syringodium isoetifolium (Si), and Thalassodendron ciliatum (Tc). In all parts of the study area, seagrass inhabits a narrow fringe along the shoreline. However, the western sides of the island have more seagrass than the eastern side because they have relatively weak waves, are surrounded or sheltered by smaller islands, have reef crests that decrease the incoming wave energies, and comprise a broader area of reef flats and shallow lagoons. These conditions are more favorable for seagrass growth.

\section{METHODS}

\subsection{Image Data}

The remote sensing image used in this research project was WorldView-2 (WV2) LV3X that had been orthorectified and thus did not require geometric correction. This project used the visible bands of WV2 images for mapping $\mathrm{AGC}_{\text {seagrass }}$ and the nearinfrared bands to perform the sunglint correction. There are time differences between the WV2 image acquisition (24 May 2012) and the field data collection (July 2011, April 2012, and November 2012). Because of seasonal seagrass patterns in the study area, there would be changes in seagrass abundance and biophysical properties composition during these times, which may influence the empirical model quality and the $\mathrm{AGC}_{\text {seagrass }}$ mapping accuracy. However, changes due to human disturbances are believed to be low since most seagrass areas are within the management of Karimunjawa National Park.

\subsection{Field Survey}

3.2.1 Seagrass sample analysis: In each sampling site, seagrass leaves were harvested in a quadrat of $1 \times 1 \mathrm{~m}\left(1 \mathrm{~m}^{2}\right)$ to standardize the measurement unit of biophysical properties. This process also took pictures of the quadrat overlaid on seagrass and recorded the coordinate of each sample. In total, 45 seagrass samples were collected. Then, the PCv and $\mathrm{AGC}_{\text {seagrass were }}$ measured for each seagrass species present in the quadrat, i.e., $\mathrm{Ea}, \mathrm{Th}, \mathrm{Cr}, \mathrm{Hu}, \mathrm{Si}$, and $\mathrm{Ho}$. The $\mathrm{PCv}$, which refers to the projected percentage of horizontal seagrass coverage within the quadrat, was estimated based on the seagrass species identified in the quadrat photos. In this research, the PCv was measured when the seagrass is submerged. The carbon stock of each species was measured in the laboratory following the proximate analysis procedure, and the $\mathrm{AGC}_{\text {seagrass }}$ in each quadrant was also calculated for each species.

These samples were used to analyze the relationship between $\mathrm{PCv}$ and $\mathrm{AGC}_{\text {seagrass }}$ at community and species levels. Regression analyses were performed first at the quadrat level consisting of single or mixed seagrass species to determine the relationship between $\mathrm{PCv}$ and $\mathrm{AGC}_{\text {seagrass }}$ at the community level and then for each species to understand their unique $\mathrm{PCv}-\mathrm{AGC}_{\text {seagrass }}$ relationship.

3.2.2 Seagrass photo-quadrat analysis: To obtain a representative number of samples to train the regression model and validate the resulting map, the distribution of seagrass samples must represent variations in seagrass conditions in the study area. This research project used a stratified random, aligned sampling to determine the photo-quadrat sample locations. The mapping unit used to determine the sampling locations in a stratified random manner was seagrass density, whose variations were identified visually on true-color-composite (TCC) WV2 image (R-G-B 5-3-2) using two interpretation keys: tone and texture. Seagrass pixels with darker tones indicate higher density and vice versa. A cluster of pixels of higher seagrass density has a smoother texture than those of lower density, where the background in between seagrasses increases the reflectance variations, roughening the texture. The location of each sample was center-aligned in the sampling's mapping unit to minimize the risk of collecting samples from adjacent units due to the combined errors of GPS and image's geometric accuracy. Afterward, the PCv of each seagrass species in each photoquadrat sample was interpreted and then converted to AGC seagrass based on the resultant regression function showing the $\mathrm{PCV}$ $\mathrm{AGC}_{\text {seagrass }}$ relationship in seagrass.

The training areas and validation samples were carefully selected by considering the spatial distributions of sample locations, species dynamics, and seagrass PCv differences so that both training area and validation samples cover similar seagrass variations. Randomly selecting the samples may lead to unequal distribution of the training areas and validation samples. Figure 1 shows the location of the study area and the field data distribution. 

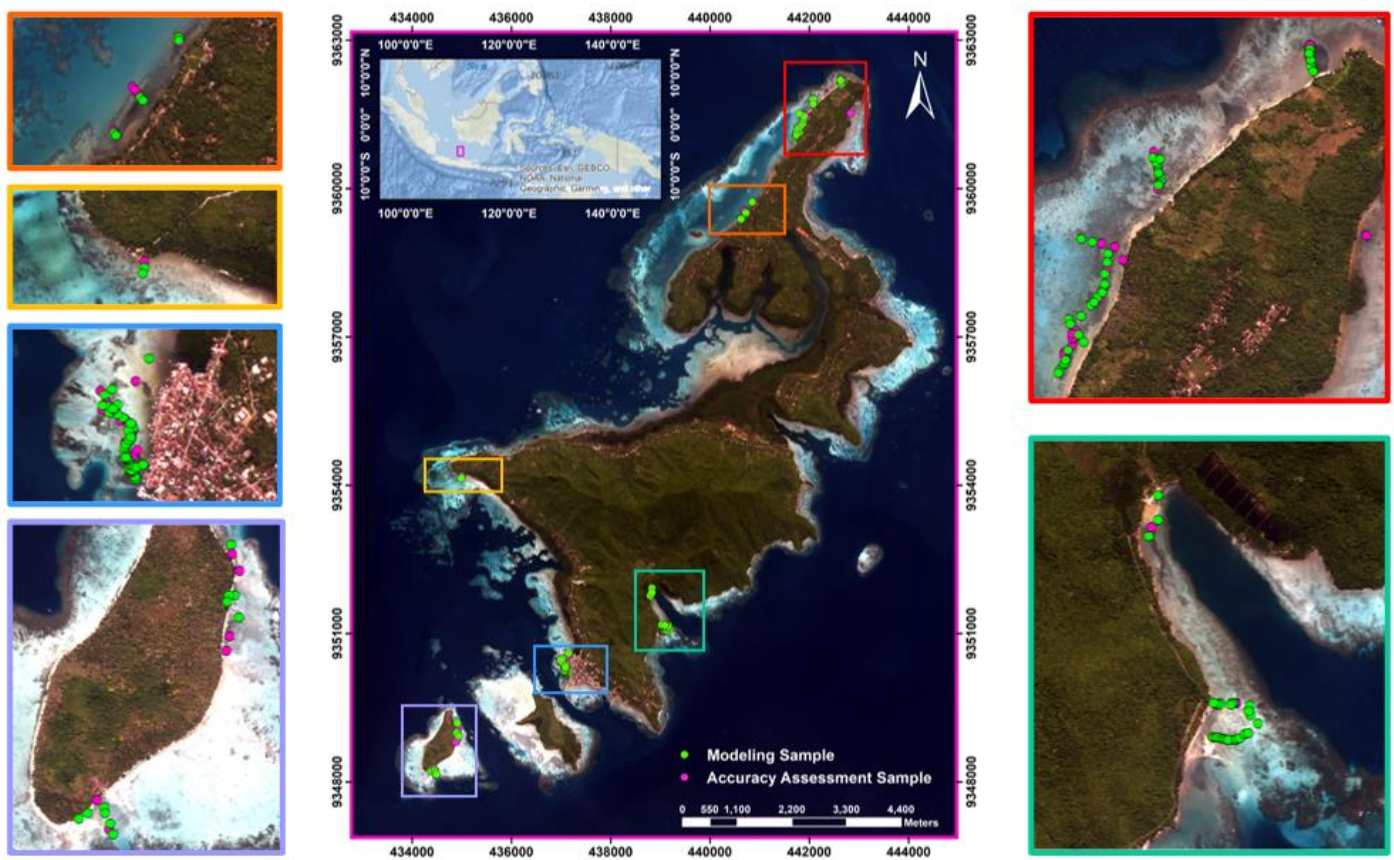

Figure 1. Satellite images of the study area and the spatial distribution of seagrass samples.

\subsection{Image Corrections}

The procedure to convert the Digital Number (DN) of WV2 images to TOA radiance $\left(L_{\mathrm{TOA}}\right)$ and TOA reflectance $\left(R_{\mathrm{TOA}}\right)$ and the parameters involved, i.e., absolute radiometric calibration factors, mean solar exoatmospheric irradiance (ESUN), and zenith angle, were described in (Updike and Comp, 2010). The atmospheric path radiance was removed from Top-ofAtmosphere (TOA) reflectance image using the Dark-Object Subtraction (DOS) algorithm (Chavez et al., 1977) to obtain Bottom-of-Atmosphere $(\mathrm{BOA})$ reflectance $\left(R_{\mathrm{BOA}}\right)$ image. The DOS method was selected because it is simple but with performance comparable to more robust methods, such as Fast Line-of-Sight Atmospheric Analysis of Hypercubes (FLAASH) and $6 \mathrm{~S}$ radiative transfer models for multispectral images (Lantzanakis et al., 2016; Wicaksono, Hafizt, 2018).

Optically deep water pixels free from sunglint were selected to predict the atmospheric offset for path-radiance removal using the DOS method (Wicaksono, Hafizt, 2018). The atmospheric offsets used to obtain $R_{\mathrm{BOA}}$ image were $0.153,0.121,0.075$, $0.049,0.038,0.029,0.022$, and 0.016 for Cyan, Blue, Green, Yellow, Red, Red-Edge, NIR1, and NIR2 band, respectively. These values were subtracted from $R_{\text {TOA }}$.

Sunglint-free reflectance $\left(R_{D}\right)$ was obtained using a method developed by (Hedley et al., 2005). Principle Component Analysis (PCA) was applied to $R_{D}$ to obtain additional variables to map seagrass species and their AGCs (Wicaksono, 2016). Inversed Model (IM) water-column correction algorithm was used to minimize the effect of the water column on the reflectance of submerged seagrass (Wicaksono, Hafizt, 2013). The IM algorithm requires information on the depth of each pixel or bathymetry $(z)$, the water-column attenuation coefficient for each band $\left(k_{i}\right)$, and the reflectance of optically deep water $\left(R_{W i}\right)$. The formula is as follows:
The $k_{i}$ for Cyan, Blue, Green, Yellow, Red, and Red-edge bands is $0.009 \mathrm{~m}^{-1}, 0.018 \mathrm{~m}^{-1}, 0.072 \mathrm{~m}^{-1}, 0.075 \mathrm{~m}^{-1}, 0.178 \mathrm{~m}^{-1}$, and 0.381 $\mathrm{m}^{-1}$, respectively (Bukata et al., 1995; Wicaksono, Hafizt, 2013). The $R_{W i}$ for the WV2 image, as adapted from Wicaksono (2016), is 0.002 (Cyan), 0.011 (Blue), 0.015 (Green), 0.005 (Yellow), 0.003 (Red), or 0.003 (Red-edge). The $z$ was generated empirically by calibrating optically shallow water reflectance with in situ bathymetry data using the band ratio method. A detailed explanation of the procedure to obtain the said bathymetry map is published in Wicaksono (2016). The resulting bathymetry map has a standard error of estimate (SEE) of 0.17 $\mathrm{m}$ for $0-1 \mathrm{~m}, 0.19 \mathrm{~m}$ for $1-2 \mathrm{~m}, 0.24 \mathrm{~m}$ for $2-3 \mathrm{~m}, 0.32 \mathrm{~m}$ for $3-$ $4 \mathrm{~m}$, and $0.78 \mathrm{~m}$ for $4-7 \mathrm{~m}$; hence, the maximum effective depth is $7 \mathrm{~m}$ (Wicaksono, 2016). Beyond this depth, the SEE increases exponentially ( $3 \mathrm{~m}$ for depth $>7 \mathrm{~m}$ ) and is, therefore, practically unusable for water column correction input.

\subsection{Seagrass species and AGC mapping}

Seagrass species were mapped to create a seagrass species mask for AGC mapping at the species level. However, mapping seagrass species individually is challenging, as already been pointed out in Phinn et al. (2008), where the accuracy of seagrass species mapping using per-pixel classification, even with hyperspectral data, is low $(<30 \%)$. Consequently, the classification scheme for the seagrass species mapping was constructed based on life form variations (Table 1).

Each photo-quadrat sample was labeled based on this classification scheme. Then, the samples were grouped into two, for training the model and classification algorithm and for assessing the accuracy: 80 samples for the class Ea (48 for training the model and classification; 32 for accuracy assessment), 50 for $\operatorname{EaThCr}(31 ; 19)$, and 83 for $\operatorname{ThCr}(53 ; 30)$.

$$
R_{B i}=10\left({ }^{(\log e(\mathrm{RDi}-\mathrm{Rwi})+2 \mathrm{kiz}))}+R_{W i} \ldots \ldots \ldots \ldots(\text { Eq. } 1)\right.
$$




\begin{tabular}{|c|c|c|}
\hline $\begin{array}{l}\text { Class } \\
\text { Name }\end{array}$ & $\begin{array}{c}\text { Species } \\
\text { Composition }\end{array}$ & Class Descriptor \\
\hline $\mathrm{Ea}$ & $\mathrm{Ea}$ & $\begin{array}{l}\text { - Species grow and extend vertically within a } \\
\text { water column. Sometimes, the leaves reach the } \\
\text { surface. } \\
\text { - Other life forms may be present in this class } \\
\text { with insignificant coverage. }\end{array}$ \\
\hline $\mathrm{ThCr}$ & $\begin{array}{c}\text { Th, Cr, Hu, Si, } \\
\text { Ho }\end{array}$ & $\begin{array}{l}\text { A mixture of horizontally growing species } \\
\text { covers the substrate and does not significantly } \\
\text { extend vertically within a water column. } \\
\text { - Other life forms may be present in this class } \\
\text { with insignificant coverage. }\end{array}$ \\
\hline EaThCr & $\begin{array}{c}\mathrm{Ea} \\
\mathrm{Th}, \mathrm{Cr}, \mathrm{Hu}, \mathrm{Si}, \\
\mathrm{Ho}\end{array}$ & $\begin{array}{l}\text { This class is a mixture between the Ea and the } \\
\text { ThCr-type species with proportional coverage. }\end{array}$ \\
\hline
\end{tabular}

Table 1. The classification scheme for seagrass species composition based on life forms (Wicaksono, Hafizt, 2013).

The Support Vector Machine (SVM) was applied only to pixels classified as seagrass to exclude non-seagrass pixels from the classification process and performed on $R_{D}, R_{B}$, and PC bands. SVM is a machine-learning classification algorithm that produces high classification accuracy, especially when the data are not normally distributed, as is frequently encountered in benthic habitat mapping with a detailed classification scheme. As a result, SVM has successfully mapped underwater objects with higher accuracy (Zhang et al., 2013; Eugenio et al., 2015). This study used the Gaussian Radial Basis Function (RBF) kernel in the SVM algorithm.

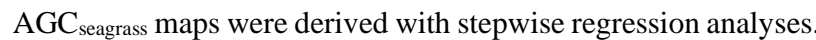
There were six predictors for empirical AGC modeling: (1) $R_{\mathrm{D}}$ bands, (2) ratio of $R_{\mathrm{D}}$ bands, (3) IM bands, (4) ratio of $R_{\mathrm{B}}$ bands, (5) Principle Component (PC) bands, and (6) ratio of PC bands. The regression analysis was performed at community and species levels, and the resulting regression functions were used to convert seagrass reflectance values into $\mathrm{AGC}_{\text {seagrass. }}$

The mapping accuracies were assessed with two approaches: the confusion matrix (Congalton and Green, 2019) for seagrass species classification and the SEE for $\mathrm{AGC}_{\text {seagrass }}$ prediction. The SEE was converted into percent using confidence interval analysis based on the lower and upper limit of the mean of the reference data (Wicaksono et al., 2011). This analysis produced a range of expected minimum and maximum accuracies of the AGC seagrass map.

\section{RESULTS}

\section{1 $\quad \mathrm{AGC}_{\text {seagrass }}$ estimation from $\mathrm{PCv}$}

4.1.1 PCv and AGC seagrass measurement: The measurement results of the harvested seagrass samples are shown in Table 2. Ea generally had lower PCv than other species because this class was found in lower density with wide gaps in between the shoots. However, its AGC was higher than other species, mainly because of its bigger leaf size. These findings provide the fundamental justification for predicting $\mathrm{AGC}_{\text {seagrass }}$ using $\mathrm{PCv}$ and mapping it at the species level.

\begin{tabular}{lcccc}
\hline \multirow{2}{*}{ Seagrass class } & \multicolumn{2}{c}{ PCv $(\%)$} & \multicolumn{2}{c}{$\mathbf{A G C}_{\text {seagrass }}\left(\mathrm{g} \mathrm{C} \mathrm{m}^{-2}\right)$} \\
& Range & Mean & Range & Mean \\
\hline At the community & $5.2-98.9$ & $45.9 \pm 26.4$ & $0.06-26.3$ & $6.5 \pm 6.7$ \\
level $(n=45)$ & & & & \\
Ea $(n=16)$ & $6.2-65.5$ & $34.1 \pm 20.3$ & $1.1-26.3$ & $11.5 \pm 8.1$ \\
Th $(n=9)$ & $5.2-98.9$ & $53.2 \pm 36.1$ & $0.3-11.2$ & $5.8 \pm 4.2$ \\
CrHu $(n=16)$ & $19.1-98.6$ & $52.7 \pm 23.9$ & $0.5-5.4$ & $2.9 \pm 1.5$ \\
SiHo $(n=4)$ & $18.9-78.5$ & $51.3 \pm 30.1$ & $0.1-0.2$ & $0.1 \pm 0.1$ \\
\hline
\end{tabular}

Table 2. PCv and AGC measurement results for each class of the harvested seagrass ( $n$ is the number of samples).
4.1.2 PCv-AGC seagrass analysis results at the community level: The PCv had a correlation coefficient ( $r$ ) of 0.37 (Sig. 95\%) and $R^{2}$ of 0.14 with $\mathrm{AGC}_{\text {seagrass. The low correlation can be addressed }}$ to variations in life forms and growth types across the seagrass species. The resultant regression function for predicting $\mathrm{AGC}_{\text {seagrass }}$ from $\mathrm{PCv}$ was $\mathbf{A G C}$ seagrass $=\mathbf{0 . 1 0 2 8}(\mathbf{P C v})+\mathbf{1 . 4 4 9}$.

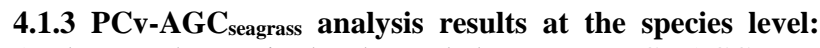
Analyses at the species level revealed a stronger PCV-AGC $\mathrm{C}_{\text {seagrass }}$ correlation than the one measured at the community level. It results from the seagrass biophysical properties that naturally vary with species. Larger species, such as Ea, grow vertically within a water column frequently up to the water surface. For seagrass species with a life form similar to Ea, their PCv may underestimate the actual $\mathrm{AGC}_{\text {seagrass, }}$ as indicated by the $R^{2}$ of the regression analyses between $\mathrm{PCVEa}$ and $\mathrm{AGC}_{\mathrm{Ea}}$, which was the lowest of all seagrass species $\left(r=0.81, R^{2}=0.66\right)$. For Ea, the $\mathrm{AGC}_{\text {seagrass }}$ was estimated using the regression equation $\mathbf{A G C} \mathbf{C}_{\mathbf{E a}}$ $=0.3179($ PCVEa $)+0.6295$.

Using $\mathrm{PCv}$ for predicting the $\mathrm{AGC}_{\text {seagrass }}$ of horizontally growing species, such as $\mathrm{Th}, \mathrm{Cr}, \mathrm{Hu}$, or $\mathrm{Si}$, was less of an issue since an increase in $\mathrm{PCV}$ corresponded to an addition in the $\mathrm{AGC}_{\text {seagrass. }}$ As a result, the $R^{2}$ between the $\mathrm{PCv}$ and $\mathrm{AGC}_{\text {seagrass }}$ of these species was higher than Ea's.

The Th percent cover $\left(\mathrm{PCv}_{\mathrm{Th}}\right)$ could explain $87 \%\left(R^{2}=0.87\right)$ of variations in the $\mathrm{AGC}_{\text {seagrass. The regression function for Th was }}$ $\mathrm{AGC}_{\mathrm{Th}}=\mathbf{0 . 1 0 6 9}\left(\mathrm{PCV}_{\mathrm{Th}}\right)+\mathbf{0 . 0 9 5 1} \mathrm{Cr}$ and $\mathrm{Hu}(\mathrm{CrHu})$ were analyzed together because the two species have an almost identical morphology and life form. In fact, the main visible difference is the shape of their leaf tip, while other leaf morphologies are visually similar. The strong relationship between their biophysical properties $\left(R^{2}=0.95\right)$ justifies the combined analysis. The regression function for $\mathrm{CrHu}$ was $\mathrm{AGC}_{\mathrm{CrHu}}=\mathbf{0 . 0 6 0 4}\left(\mathrm{PCV}_{\mathrm{CrHu}}\right) \mathbf{- 0 . 1 7 6 7}$. Si and Ho, the minor species found in some sample locations, were associated with more dominant seagrass species such as Th and Cr. Although Si and Ho have different life forms, their $\mathrm{AGC}_{\text {seagrass }}$ were almost similar. For this reason, and because they were only a minor component of the seagrass beds in the study area, their analyses were also combined $(\mathrm{SiHo})\left(r=0.97, R^{2}=0.94\right)$. The resultant regression function for $\mathrm{SiHo}$ was $\mathrm{AGC}_{\mathrm{SiHo}}=\mathbf{0 . 0 0 2 6 8}\left(\mathrm{PCV}_{\mathrm{SiHo}}\right)$ 0.0022 .

\subsection{Seagrass species composition mapping}

The most accurate seagrass species composition map based on life forms had an OA of $76.11 \%$ obtained from PC bands. The ThCr classification was the most accurate, as shown by its high user's accuracy (UA) and producer's accuracy (PA) (Table 3), because it consisted of single life forms with almost similar leaf morphology. Meanwhile, EaThCr had lower accuracy compared with $\mathrm{ThCr}$ since it was a mixed life form class. Nevertheless, because EaThCr species were primarily found with higher density, mapping was relatively feasible because most of the reflectance was from the seagrass. Species with lower densities were more difficult to classify because the reflectance of the background substrates obscured the reflectance of the seagrass. Ea had a similar UA to but significantly lower PA than EaThCr, causing the extent of the Ea class to be highly underestimated; only $3.6 \% \mathrm{Ea}$ in the field was correctly classified, while the majority was misclassified as either EaThCr or ThCr. The life form of this class and the reflectance of substrates in between $\mathrm{Ea}$ shoots may be the sources of the misclassification. The three generated life form masks represented the distribution of specific seagrass species composition, namely: $\mathrm{Ea}$, $\mathrm{EaThCr}$, and $\mathrm{ThCr}$ 
masks. The empirical $\mathrm{AGC}_{\text {seagrass }}$ model at the species level was performed based on these three species composition classes.

\begin{tabular}{cccccc}
\hline \multirow{2}{*}{$\begin{array}{c}\text { Seagrass } \\
\text { class }\end{array}$} & \multirow{2}{*}{ PA (\%) } & \multirow{2}{*}{ UA $(\boldsymbol{\%})$} & \multicolumn{3}{c}{ Misclassification rate (\%) } \\
\cline { 4 - 6 } $\mathrm{Ea}$ & 3.60 & 50.00 & Ea & EaThCr & ThCr \\
\hline EaThCr & 63.96 & 50.00 & 3.60 & 41.44 & 54.95 \\
ThCr & 94.98 & 82.98 & 0.00 & 5.02 & 32.43 \\
\hline
\end{tabular}

Table 3. Accuracy assessment results of the seagrass species composition mapping using SVM.

\section{3 $\quad$ AGC $_{\text {seagrass }}$ mapping}

The PCv interpreted from each photo-quadrat sample was used to estimate the $\mathrm{AGC}_{\text {seagrass }}$ at the species level using the corresponding species composition class regression function. The $\mathrm{AGC}_{\text {seagrass }}$ of each quadrat is the sum of the AGCs of all seagrass species present in the quadrat. Afterward, each sample was labeled based on the species composition class described in Table 1. The mean $\mathrm{AGC}_{\text {seagrass }}$ from all photo-quadrat samples were $11.33 \mathrm{~g} \mathrm{C} \mathrm{m}^{-2}$ for training areas and $10.65 \mathrm{~g} \mathrm{C} \mathrm{m}^{-2}$ for validation samples.

4.3.1 $\mathrm{AGC}_{\text {seagrass }}$ mapping at the community level: The

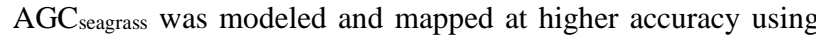
band ratio (Table 4). The $\mathrm{AGC}_{\text {seagrass }}$ map generated with the ratio of $R_{D}$ bands had $58.79 \%$ accuracy (SEE $=5.41 \mathrm{~g} \mathrm{C} \mathrm{m}^{-2}$ ), which was $10 \%$ higher than the best result of the single band model $\left(R_{B}\right.$ bands, $48.69 \%$ accuracy, $\mathrm{SEE}=6.69 \mathrm{~g} \mathrm{C} \mathrm{m}^{-2}$ ). The single band and band ratio results showed a similar pattern where AGCs below $10 \mathrm{~g} \mathrm{C} \mathrm{m}^{-2}$ were overestimated, while AGCs above $15 \mathrm{~g} \mathrm{C}$ $\mathrm{m}^{-2}$ were underestimated. Thus, only AGCs in the range of 10 $15 \mathrm{~g} \mathrm{C} \mathrm{m}^{-2}$ were correctly predicted.

\begin{tabular}{|c|c|c|c|c|}
\hline Model & $R^{2}$ & Regression Function & $\mathrm{SE}\left(\mathrm{g} \mathrm{C} \mathrm{m}^{2}\right)$ & Accuracy (\%) \\
\hline \\
\hline & \multicolumn{4}{|c|}{ Single band } \\
\hline$R_{\mathrm{D}}$ bands & 0.303 & $34.998 \cdot 123.544 R_{\text {DR Red }}$ & 7.59 & 60.2 \\
\hline$R_{\mathrm{B}}$ bands & 0.171 & $76.541 \cdot 316.784 \mathrm{RB}_{\mathrm{B} \text { men }}$ & 9.7 & 49.14 \\
\hline PC bands & 0.274 & $22.648 \cdot 0.039(\mathrm{PC1})$ & 7.92 & 59.46 \\
\hline \multicolumn{5}{|l|}{ Band ratio } \\
\hline$R_{\mathrm{D}}$ bands & 0.28 & 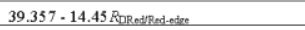 & 6.86 & $64.73^{*}$ \\
\hline$R_{\mathrm{B}}$ bands & 0.247 & 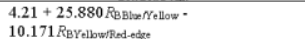 & 7.19 & 63.06 \\
\hline PC bands & 0.163 & $14.207+5.303 \mathrm{c}-12(\mathrm{PC} 16)+0.609(\mathrm{PC} 34)$ & 7.10 & 63.51 \\
\hline \multicolumn{5}{|c|}{ EaThCr class } \\
\hline \multicolumn{5}{|l|}{ Single band } \\
\hline$R_{\mathrm{D}}$ bands & 0.335 & $64.99-138.719 R_{\mathrm{DC} Y \mathrm{pan}}$ & 4.57 & 68.77 \\
\hline$R_{\mathrm{B}}$ bands & ns & ns & ns & ns \\
\hline PC bands & 0.316 & $15.986 \cdot 0.033(\mathrm{PC} 1)$ & 4.61 & 68.54 \\
\hline \multicolumn{5}{|l|}{ Band ratio } \\
\hline$R_{\mathrm{D}}$ bands & 0.283 & 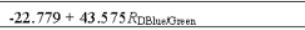 & 4.38 & 69.59 \\
\hline$R_{\mathrm{B}}$ bands & 0.196 & 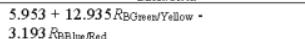 & 4.32 & $7.02 *$ \\
\hline PC bands & ns & $\begin{array}{l}\text { 3.193 KepluerRed } \\
\text { ns }\end{array}$ & ns & $\frac{70.02^{*}}{\mathrm{~ns}}$ \\
\hline \multicolumn{5}{|l|}{ ThCr class } \\
\hline \multicolumn{5}{|l|}{ Single band } \\
\hline$R_{\mathrm{D}}$ bands & 0.617 & $21.162 \cdot 42.581 R_{\text {pred }} \cdot 82.213 R_{\text {prodedect }}$ & 3.41 & 36.55 \\
\hline$R_{\mathrm{B}}$ bands & 0.546 & $35.138 \cdot 328.475 \mathrm{R}_{\mathrm{B} \text { Red }}$ & 3.4 & 37.88 \\
\hline PC bands & 0.65 & $9.758 \cdot 0.017(\mathrm{PC} 1) \cdot 0.294(\mathrm{PC} 6)$ & 3.04 & 43.49 \\
\hline \multicolumn{5}{|l|}{ Band ratio } \\
\hline$R_{\mathrm{D}}$ bands & 0.185 & 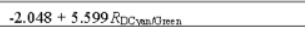 & 2.55 & $55.08^{*}$ \\
\hline$R_{\mathrm{B}}$ bands & 0.117 & $3.507+0.849 R_{\text {B Blow Rodeded o }}$ & 2.71 & 52.37 \\
\hline PC bands & 0.217 & $4.832 \cdot 4.633 \mathrm{e}-10(\mathrm{PC} 13)+(\mathrm{PC} 25)$ & 3.12 & 45.09 \\
\hline \multicolumn{5}{|c|}{ At-community level } \\
\hline \multicolumn{5}{|l|}{ Single band } \\
\hline$R_{\mathrm{D}}$ bands & 0.271 & $26.981 \cdot 103.476 R_{\text {DRed }}$ & 7.48 & 41.76 \\
\hline$R_{\mathrm{B}}$ bands & 0.211 & $49.904 \cdot 233.584 R_{\text {B Yellow }}$ & 6.69 & 48.69 \\
\hline PC bands & 0.266 & $16.912 \cdot 0.031(\mathrm{PC} 1) \cdot 0.083(\mathrm{PC} 3)$ & 7.44 & 42.09 \\
\hline \multicolumn{5}{|l|}{ Band ratio } \\
\hline$R_{\mathrm{D}}$ bands & 0.285 & 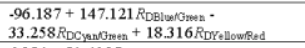 & 5.41 & $58.79^{*}$ \\
\hline$R_{\mathrm{B}}$ bands & 0.192 & 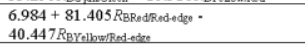 & 5.76 & 56.13 \\
\hline PC bands & 0.023 & $10.906 \cdot 0.041$ (PC56) & 7.39 & 43.66 \\
\hline
\end{tabular}

Table 4. Accuracy assessment results of the $\mathrm{AGC}_{\text {seagrass }}$ mapping.

4.3.2 $\mathrm{AGC}_{\text {seagrass }}$ mapping at the species level: Compared with mapping at the community level (Table 4), the AGC seagrass maps generated at the species level were higher in accuracy for Ea and
EaThCr but lower for ThCr. The mean AGCs were 15.41 $\pm 6.07 \mathrm{~g}$ $\mathrm{C} \mathrm{m}^{-2}$ for Ea (estimated from $\left.46.67 \pm 19.21 \% \mathrm{PCv}\right), 11.73 \pm 4.42 \mathrm{~g}$ $\mathrm{C} \mathrm{m}^{-2}$ for EaThCr $(64.49 \pm 17.22 \% \mathrm{PCv})$, and $4.89 \pm 2.16 \mathrm{~g} \mathrm{C} \mathrm{m}^{-2}$ for $\mathrm{ThCr}(50.91 \pm 19.82 \% \mathrm{PCv})$. Despite having the lowest $\mathrm{PCv}$, Ea had the highest mean AGC because its species constituents had a significantly larger size than species in other classes.

The predicted AGCEa was saturated beyond $20 \mathrm{~g} \mathrm{C} \mathrm{m}^{-2}$, while for the $\mathrm{AGC}_{\mathrm{EaThCr}}$ was saturated after $15 \mathrm{~g} \mathrm{C} \mathrm{m}^{-2}$; hence, the actual amount of aboveground carbon stored in seagrass with high predicted AGC is underestimated. In contrast, the predicted $\mathrm{AGC}_{\mathrm{ThCr}}$ was overestimated, especially for AGC less than $8 \mathrm{~g} \mathrm{C}$ $\mathrm{m}^{-2}$. Based on these results, seagrass reflectance captured by remote sensing can correctly map $\mathrm{AGC}_{\text {seagrass }}$ when it is in the range of 15-20 $\mathrm{g} \mathrm{C} \mathrm{m}^{-2}$ for Ea, 10-15 $\mathrm{g} \mathrm{C} \mathrm{m}^{-2}$ for EaThCr, and 4-8 $\mathrm{g} \mathrm{C} \mathrm{m}^{-2}$ for ThCr. Accordingly, the $\mathrm{AGC}_{\text {seagrass }}$ in the study area was estimated at around $13.39 \mathrm{tC}$ from $1.21 \mathrm{~km}^{2}$ of seagrass habitat. In detail, $\mathrm{AGC}_{\mathrm{Ea}}$ was estimated at around $0.35 \mathrm{t} \mathrm{C}$, $\mathrm{AGC}_{\mathrm{EaThCr}}$ at $5.84 \mathrm{t} \mathrm{C}$, and $\mathrm{AGC}_{\mathrm{ThCr}}$ at $3.24 \mathrm{t} \mathrm{C}$.

\section{DISCUSSION}

This research utilized seagrass PCv for rapid and non-destructive estimation to obtain $\mathrm{AGC}_{\text {seagrass }}$ at community and species levels. $\mathrm{PCv}$ and $\mathrm{AGC}_{\text {seagrass }}$ show a weak correlation at the community level, causing the approximated $\mathrm{AGC}_{\text {seagrass }}$ to be less accurate. Therefore, the equation provided in Wahyudi et al. (2020) is suggested for converting seagrass $\mathrm{PCv}$ into $\mathrm{AGC}_{\text {seagrass without }}$ considering species variations. Nevertheless, the correlation coefficients and $R^{2}$ values are significantly higher when approximating $\mathrm{AGC}_{\text {seagrass }}$ from $\mathrm{PCv}$ at the species level. Besides, estimating $\mathrm{AGC}_{\text {seagrass }}$ from the $\mathrm{PCv}$ interpreted from photoquadrat samples is relatively fast and, thus, allows more samples to be collected.

At the community level, the highest $\mathrm{AGC}_{\text {seagrass }}$ map accuracy is $58.79 \%$ ( $\mathrm{SEE}=5.41 \mathrm{~g} \mathrm{C} \mathrm{m}^{-2}$ ). To obtain better accuracy, mapping AGC at the species level is deemed necessary. It requires an accurate seagrass species map, and this research has successfully generated a seagrass species composition map with $76.11 \%$ OA. However, although this percentage is comparable to previous works by Roelfsema et al. (2014) and Koedsin et al. (2016), the accuracy of classes comprising individual seagrass species is not similarly high. In this research, Ea has a very low PA and underestimated extent. Under these conditions, it is also

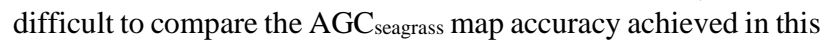
study with that in previous work. Therefore, the results of this research cannot be directly compared with other studies but can be used as the baseline for future mapping activities using seagrass classification with similar complexity.

This research also highlights some improvements in estimating and mapping the $\mathrm{AGC}_{\text {seagrass }}$ at the species level. For instance, the $\mathrm{AGC}_{\mathrm{EaThCr}}$ map has the highest accuracy, followed by AGC $\mathrm{Ea}_{\mathrm{E}}$ and $\mathrm{AGC}_{\mathrm{ThCr}}$ maps. Consisting of seagrass species with various life forms, EaThCr is expected to be the most challenging class to model. However, because its AGCs are in the range of 5 to $25 \mathrm{~g}$ $\mathrm{C} \mathrm{m}^{-2}$, species belonging to this class can be mapped at higher accuracy. Furthermore, Ea can be modeled quite accurately because the pixels categorized into this class are composed of only one species, with biomass having a negative linear correlation with the percent cover of sand or any background substrates. Therefore, the fraction of seagrass reflectance that composes the pixel mainly comes from Ea, and it effectively represents the abundance of Ea within the pixel. Assuming the background reflectance does not vary greatly, variations in 
biophysical properties are the main cause of changes in Ea reflectance. Moreover, Ea grows sparsely; thus, unless mixed with other species, bare substrates in between the shoots create larger gaps and produce background reflectance that affects the total reflectance of seagrass. This condition may also negate the image pixel value that is easily saturated. Consequently, Ea has a higher saturation threshold $\left(20 \mathrm{~g} \mathrm{C} \mathrm{m}^{-2}\right)$ than other classes $(15 \mathrm{~g}$ $\left(\mathrm{m}^{-2}\right)$.

Three important findings regarding the $\mathrm{AGC}_{\text {seagrass }}$ mapping are: (1) mapping low $\mathrm{AGC}_{\text {seagrass }}$ is difficult because the background reflectance largely contributes to and alters the resultant seagrass reflectance, (2) mapping high $\mathrm{AGC}_{\text {seagrass }}$ is also challenging because seagrass reflectance is saturated at higher AGC due to the high energy absorption by seagrass bed with higher biomass, and (3) mapping seagrass with medium AGC is more feasible since the reflectance of background object is limited and yet to be saturated.

There are not many published papers on $\mathrm{AGC}_{\text {seagrass }}$ mapping in Indonesia. For instance, Astuty et al. (2019) mapped AGC seagrass in Parang Island using PlanetScope-based depth-invariance bottom index and produced $66.90 \%$ accuracy with SEE of $4.78 \mathrm{~g}$ $\mathrm{C} \mathrm{m}^{-2}$. The mapping was conducted at the community level with higher accuracy than the current study owing to the capability of
PlanetScope to obtain images closest to the date of the field survey. As a result, there was no temporal error due to seasonal patterns of seagrass in their study.

This research acknowledges that one of the issues affecting the

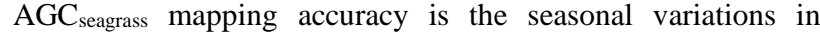
seagrass presence, especially when the image acquisition does not temporally coincide with field data collection. This issue can be addressed in future studies by using a high temporal-resolution image, such as PlanetScope. Although PlanetScope has lower spectral and spatial resolution than WV2, it offers flexibility in selecting the acquisition date, thus enabling users to obtain images during field data collection and removing the error caused by seasonal variations in seagrass presence in the empirical $\mathrm{AGC}_{\text {seagrass }}$ model.

Finally, the regression equations developed in this study are expected to improve the availability of $\mathrm{AGC}_{\text {seagrass }}$ data that is currently lacking due to the laboratory analysis and destructive harvest involved in their acquisition, especially for seagrass species presented in this study. With more availability, this information can be used to train remote sensing images and

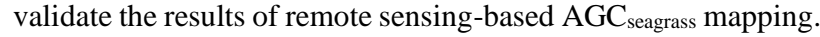
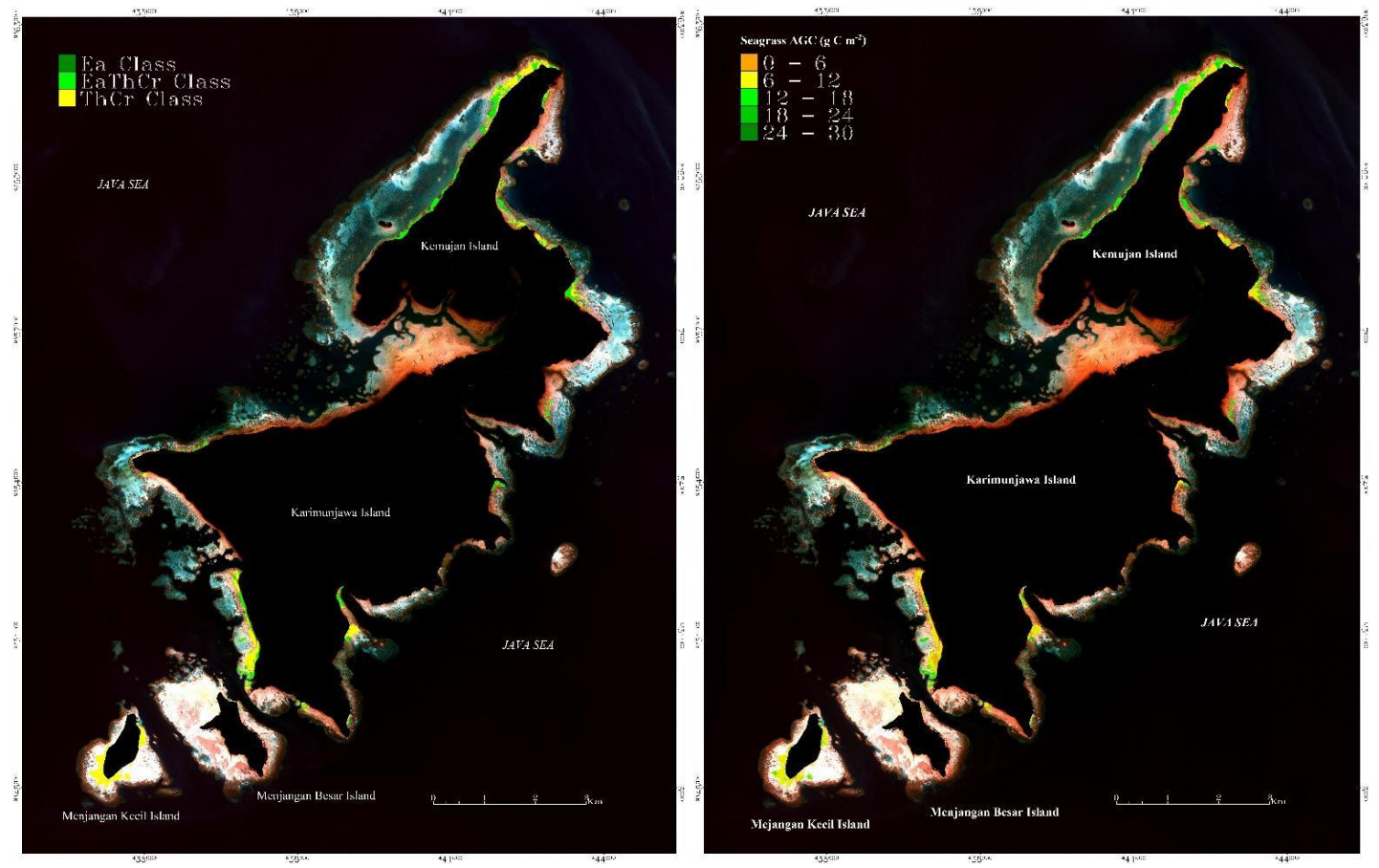

Figure 2. Life form-based seagrass species composition map with $76.11 \% \mathrm{OA}$, based on SVM classification results using WV2 PC

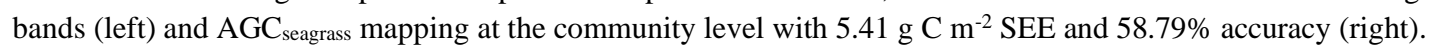

\section{CONCLUSIONS}

This research has developed a rapid aboveground seagrass carbon

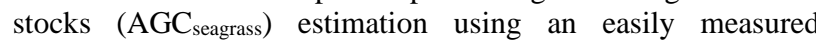
parameter, seagrass $\mathrm{PCv}$. Estimating $\mathrm{AGC}_{\text {seagrass }}$ from $\mathrm{PCv}$ produces more accurate results when conducted individually for each species. Hence, this research recommends using speciesspecific $\mathrm{PCv}-\mathrm{AGC}_{\text {seagrass }}$ equation to approximate $\mathrm{AGC}_{\text {seagrass }}$ from PCv. Furthermore, $\mathrm{AGC}_{\text {seagrass }}$ can be modeled and mapped from remote sensing data. At the community level, the $\mathrm{AGC}_{\text {seagrass }}$ map generated from WV2 images is $58.79 \%$ accurate
$\left(\mathrm{SE}=5.41 \mathrm{~g} \mathrm{C} \mathrm{m}^{-2}\right)$. Meanwhile, at the species level, the accuracy increases significantly for $\mathrm{Ea}\left(64.73 \%, \mathrm{SEE}=6.86 \mathrm{~g} \mathrm{C} \mathrm{m}^{-2}\right)$ and $\mathrm{EaThCr}\left(70.02 \%, \mathrm{SEE}=4.32 \mathrm{~g} \mathrm{C} \mathrm{m}^{-2}\right)$ but decreases for $\mathrm{ThCr}$ $\left(55.08 \%, \mathrm{SEE}=2.55 \mathrm{~g} \mathrm{C} \mathrm{m}^{-2}\right)$. The results indicate that $\mathrm{WV} 2$ image reflectance can correctly map $\mathrm{AGC}_{\text {seagrass }}$ in the study area when it is in the range of $15-20 \mathrm{~g} \mathrm{C} \mathrm{m}^{-2}$ for Ea, $10-15 \mathrm{~g} \mathrm{C} \mathrm{m}^{-2}$ for EaThCr, and $4-8 \mathrm{~g} \mathrm{C} \mathrm{m}^{-2}$ for ThCr. Finally, $\mathrm{AGC}_{\text {seagrass }}$ in the study area is estimated at $13.39 \mathrm{t} \mathrm{C}$. 


\section{ACKNOWLEDGMENTS}

This research was funded by WCR Research Grant No. 4485/UN1/DITLIT/DIT-LIT/PT/2021.

\section{REFERENCES}

Astuty, I. S., Wicaksono, P., 2019. Seagrass species composition and above-ground carbon stock mapping in Parang Island using Planetscope image. Proceedings SPIE Volume 11311, Sixth Geoinformation Science Symposium, 11311. doi.org/10.1117/12.2549137.

Bell, S. S., Fonseca, M. S., Stafford, N. B., 2006: Seagrass ecology: New contributions from a landscape perspective. Seagrasses: Biology, Ecology and Conservation, 625-645. doi.org/10.1007/978-1-4020-2983-7_26.

Bukata, R. P., Jerome, J. H., Kondratyev, K. Y., Pozdnyakov, D. V., 2018: Optical properties and remote sensing of inland and coastal waters. CRC press, Boca Raton. doi.org/10.1201/9780203744956.

Chavez, P., Berlin, G., Mitchell, W., 1977. Computer Enhancement Techniques of Landsat MSS Digital Images for Landuse/Landcover Assessments. Remote Sensing of Earth Resources, 6, 259.

Congalton, R. G., Green, K., 2019: Assessing the Accuracy of Remotely Sensed Data: Principles and Practices (3th ed.). CRC Press, Boca Raton.

Duffy, J. E., 2006. Biodiversity and the functioning of seagrass ecosystems. Marine Ecology Progress Series, 311, 233-250. doi.org/10.3354/meps311233.

Eugenio, F., Marcello, J., Martin, J., 2015. High-Resolution Maps of Bathymetry and Benthic Habitats in Shallow-Water Environments Using Multispectral Remote Sensing Imagery. IEEE Transactions on Geoscience and Remote Sensing, 53(7), 3539-3549. doi.org/10.1109/TGRS.2014.2377300.

Hedley, J. D., Harborne, A. R., Mumby, P. J., 2005. Simple and robust removal of sun glint for mapping shallow-water benthos. International Journal of Remote Sensing, 26(10), 2107-2112. doi.org/10.1080/01431160500034086.

Hossain, M. S., Bujang, J. S., Zakaria, M. H., Hashim, M., 2015. The application of remote sensing to seagrass ecosystems: an overview and future research prospects. International Journal of $\begin{array}{lll}\text { Remote Sensing, 36(1), 61-114. } & \text {. }\end{array}$ doi.org/10.1080/01431161.2014.990649.

Koedsin, W., Intararuang, W., Ritchie, R. J., Huete, A., 2016. An integrated field and remote sensing method for mapping seagrass species, cover, and biomass in Southern Thailand. Remote Sensing, 8(4). doi.org/10.3390/rs8040292.

Lantzanakis, G., Mitraka, Z., Chrysoulakis, N., 2016. Comparison of physically and image based atmospheric correction methods for Sentinel-2 satellite imagery. Proceedings SPIE, Fourth International Conference on Remote Sensing and Geoinformation of the Environment, 9688, 96880A. doi.org/10.1117/12.2242889.
Misbari, S. B., 2017. Quantification of Submerged Seagrass Total Aboveground Biomass for Malaysian Coastal Waters Using Remote Sensing Data. Universiti Teknologi Malaysia, Kuala Lumpur, Malaysia.

Phinn, S. R., Roelfsema, C. M., Dekker, A., Brando, V., Anstee, J., 2008. Mapping seagrass species, cover and biomass in shallow waters: An assessment of satellite multi-spectral and airborne hyper-spectral imaging systems in Moreton Bay (Australia). Remote Sensing of Environment, 112(8), 3413-3425. doi.org/10.1016/j.rse.2007.09.017.

Roelfsema, C. M., Lyons, M., Kovacs, E. M., Maxwell, P., Saunders, M. I., Samper-Villarreal, J., Phinn, S. R., 2014. Multitemporal mapping of seagrass cover, species and biomass: A semi-automated object based image analysis approach. Remote

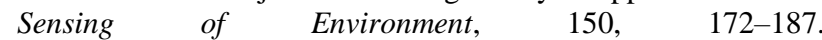
doi.org/10.1016/j.rse.2014.05.001.

Tamondong, A. M., Cruz, C. A., Guihawan, J., Garcia, M., Quides, R. R., Cruz, J. A., Blanco, A. C., 2018. Remote sensingbased estimation of seagrass percent cover and LAI for above ground carbon sequestration mapping. Proceedings SPIE Volume 10778, 10778. doi.org/10.1117/12.2324695.

Updike, T., Comp, C., 2010. Radiometric Use of WorldView-2 Imagery. DigitalGlobe ${ }^{\circledR}$, Longmont.

Wahyudi, A. J., Rahmawati, S., Irawan, A., Hadiyanto, H., Prayudha, B., Hafizt, M., Afdal, A., Adi, N. S., Rustam, A., Hernawan, U. E., Rahayu, Y. P., Iswari, M. Y., Supriyadi, I. H., Solihudin, T., Ati, R. N. A., Kepel, T. L., Kusumaningtyas, M. A., Daulat, A., Salim, H. L., Sudirman, N., Suryono, D. D., Kiswara, W., 2020. Assessing Carbon Stock and Sequestration of the Tropical Seagrass Meadows in Indonesia. Ocean Science Journal, 55(1), 85-97. doi.org/10.1007/s12601-020-0003-0.

Wicaksono, P., 2016. Improving the accuracy of multispectralbased benthic habitats mapping using image rotations: The application of principle component analysis and independent component analysis. European Journal of Remote Sensing, 49, 433-463. doi.org/10.5721/EuJRS20164924.

Wicaksono, P., Danoedoro, P., Hartono, H., Nehren, U., Ribbe, L., 2011. Preliminary work of mangrove ecosystem carbon stock mapping in small island using remote sensing: above and below ground carbon stock mapping on medium resolution satellite image. Remote Sensing for Agriculture, Ecosystems, and Hydrology XIII, 8174, 81741B. doi.org/10.1117/12.897926.

Wicaksono, P., Hafizt, M., 2013. Mapping seagrass from space: Addressing the complexity of seagrass LAI mapping. European Journal of Remote Sensing, 46(1), 18-39. doi.org/10.5721/EuJRS20134602.

Wicaksono, P., Hafizt, M., 2018. Dark target effectiveness for dark-object subtraction atmospheric correction method on mangrove above-ground carbon stock mapping. IET Image Processing, 12(4), 582-587. doi.org/10.1049/iet-ipr.2017.0295.

Zhang, C., Selch, D., Xie, Z., Roberts, C., Cooper, H., Chen, G., 2013. Object-based benthic habitat mapping in the Florida Keys from hyperspectral imagery. Estuarine, Coastal and Shelf Science, 134, 88-97. doi.org/10.1016/j.ecss.2013.09.018. 